\title{
Altın Orda-Rus Mücadelesinin Edebiyata Yansıması: Zadonşina Destanı*
}

\author{
Mualla Uydu Yücel $^{* *}$ \\ Ainagul Saginayeva***
}

\begin{abstract}
Öz
XIII. yüzyılın ilk çeyreğinden itibaren Rus topraklarını hâkimiyetleri altına almaya başlayan Moğollar, bu yüzyılın ikinci yarısından itibaren gittikçe güçlenerek çeşitli Türk boylarını da içlerine alarak Altın Orda devletinin kurulmasına öncülük etmişlerdir. Nitekim Altın Orda devletinin güçlenmesi çok kısa süre içerisinde tamamlanmış ve Rus knyazları bu güç karşısında gerek siyasî gerekse askerî olarak bir varlık gösterememişlerdir. Ancak XIV. yüzyılın ikinci yarısından sonra Altın Orda’da başlayan güç kaybının en net görüntüsü 1380 yılında Moskova Knyazı Dmitriy ile Altın Orda Emiri Mamay Mirza arasında gerçekleşen Kulikovo Meydan Muharebesinde görülmüştür. Bu savaşta Altın Orda büyük bir zaafa uğramıştır. Tarihi süreç değerlendirildiğinde Kulikovo, Altın Orda için kaçınılmaz sonu yani bir dağılma ve yok oluşun başlangıcını ifade ederken, Ruslar içinse birleşerek duraklama dönemlerinden çıkmalarını ve Kalka’nın intikâmını almalarını sağlayan büyük bir zaferi ifade etmiştir. Bu zaferin bir diğer önemli özelliği ise Rusların bu savaştan sonra "Rus milleti" bilincine sahip olarak tarih sahnesinde yerlerini almış olmalarıdır. Bu savaşın hemen akabinde yazıldığı düşünülen destanlardan biri de Zadonşina destanıdır. Çalışmamızda destanın metni Türkçeye çevrilerek, yorumu yapılmaya çalışılmıştır.
\end{abstract}

\section{Anahtar Kelimeler}

Rus knyazları, Altın Orda, Moskova, Mamay, destan, Dmitriy.

\footnotetext{
* Bu çalışma 2014 yılında düzenlenen 11. Milli Türkoloji Kongresinde sunulması planlanan tebliğ esas alınarak hazırlanmıștır.

Geliş Tarihi: 01 Mart 2017 - Kabul Tarihi: 22 Şubat 2018

Bu makaleyi şu şekilde kaynak gösterebilirsiniz:

Uydu Yücel, Mualla ve Ainagul Saginayeva (2020). "Altın Orda-Rus Mücadelesinin Edebiyata Yansıması: Zadonşina Destanı”. bilig - Türk Dünyası Sosyal Bilimler Dergisi 93: 149-179.

** Prof. Dr., İstanbul Üniversitesi, Edebiyat Fakültesi, Tarih Bölümü - İstanbul/Türkiye ORCID ID: 0000-0002-1595-2106 mualla.yucel@istanbul.edu.tr

${ }^{* * *}$ Dr., Al-Farabi Kazak Ulusal Üniversitesi, Tarih Bölümü - Almatı/Kazakistan

ORCID ID: 0000-0003-4871-972X

aikos-1978@mail.ru
} 


\section{Giriş}

Rus milletinin "milletleşme sürecini” başlatan ve tartışmasız en büyük zafer olarak görülen Kulikovo Savaşı ve Zaferi hakkında günümüze kadar Rusya’da pek çok araştırma yapılmıştır. Türkiye'de ise tarafımızdan yapılan çalışmaya kadar (Yücel 2008) geniş kapsamlı bir çalışma maalesef yapılmamıştır. Zadonşina Destanını incelemeden önce bu destanın ortaya çıkmasına ve yazılmasına sebep olan siyasi sürece kısaca değinelim.

Altın Orda Devleti Cengiz Han'ın Cuci adlı oğlundan olan torunu Batu tarafından kurulmuştur. Batu, 1229 yılından başlayarak 1242-1243 yıllarına kadar bütün Deşt-i Kıpçak ve Bulgar Bölgesi ile Karpat Dağları ve Tuna’ya kadar uzanan geniş bir coğrafyada hâkimiyet kurmuştur (Kafalı 1976: 20).

Ruslar ile Moğollar arasında 31.05.1223 yılında Kalka Irmağı kenarında gerçekleşen ilk karşılaşma Moğolların zaferi ile neticelenmiş ve bu zaferden sonra Moğollar, Rus bozkırlarında 1223'den 1256'ya kadar 22 yıl gibi kısa bir süre içerisinde olanca hızları ile hâkimiyet kurmaya devam etmişlerdir.

\section{Kulikovo Savaşı Öncesi Altın Orda-Rus Münasebetleri}

1223 Yılının 31 Mayıs'ında Kalka'da yaşanılan büyük hezimeti Ruslar hiçbir zaman unutmamışlar ve intikamlarını almak için Altın Orda’nın zayıf bir anını yakalama fırsatını kollamaya başlamışlardır ki bu fırsatı tam 156 yıl sonra 1380 tarihinde bulmuşlardır.

Atın Orda’nın yayıldığı coğrafyanın büyük bir kısmı Türk boylarının özellikle de Kıpçak boyunun yaşadığı coğrafya olduğundan zamanla hem siyasî hem de kültürel olarak bir Türk devleti yapısına bürünmüştür. Kulikovo Savaşı'na kadar Altın Orda'da pek çok hükümdar tahta geçmiştir. Bunlar Berke 1266, Mengü Timur (1266-1282), Nogay (1267-1280), Tuda-Münge Han (1282-1287) Tulubuğa (Tula-Buka Han) (1287-1290), Tokta Han (12911313), Özbek Han (1313-1340); Can1-Bek (1342-1357); Berdi-Bek (13571360); Kulna/Kulpa (1360) hanlardır. Altın Orda'da ilk gerileme belirtileri daha Canı-Bek Han (1342-1357) döneminde ortaya çıkmış ve BerdiBek'in rakiplerinden biri olan Kulna tarafından öldürülmesi ile devlet bir dağılma sürecine girmiştir. Bundan sonra Altın Orda tarihinde duraklama (fetret) dönemi denilen bir dönem yaşanmıştır. Kulpa’nın, kardeşi Nevruz tarafından öldürülmesi ile karışıklıklar artmış ve 1360'dan 1380'e yani Toktamış'ın Altın Orda'nın başına geçmesine kadar taht için birbirleri ile 
savaşan 25 'ten fazla han başa geçmiştir (Yakubovskiy 1992: 110, 116).

IX. Yüzyıldan beri Türk devletlerinin ağır baskılarını yakından hisseden Ruslar, Altın Orda’nın gücüne fazla bir mukavemet gösteremeyerek boyun eğmek zorunda kalmışlardır. Hâkimiyet yıllarında Rus Knyazları, Altın Orda hükümdarlarından izin almaları şartı ile eskisi gibi her biri kendi bölgesini "Knyaz" sıfatı ile idare etmiştir. Bir taraftan hükümdardan izin alma şartı; diğer taraftan aralarındaki "Büyük Knyaz" olma isteği ve hırsı uzun süre Rusların dış güçlere karşı bir birliktelik ortaya koymalarına engel olmuştur. Tabii bu durum Ruslara uzun sürecek bir Moğol ve Altın Orda hâkimiyeti yaşattırmıştır (Kurat 1987: 71-79). Altın Orda hâkimiyetine karşı zaman zaman isyan hareketleri yaşanmışsa da bu ayaklanmalar bastırılmıştır (Nasonov 1940: 52, Kafalı 1976: 55). 1360 yilından 1380 yılında kadar Altın Orda’da çıkan karışıklıklar bir taraftan Rus knyazlarının rahat bir nefes almalarını sağlamış, diğer taraftan da güçlenmelerine katkı sunmuştur. Altın Orda tahtına çıkan Hızır, devletin durumunu güçlendirmeyi denemişse de o da oğullarının düzenlediği suikaste kurban gitmiştir (Yakubovskiy 1992: 117). Altın Orda’da karışıklıklar bu dönemde daha da çok artmış; hem Cengiz sülâlesinden gelenler hem de Moğol askerî teşkilatında önemli görevler üstlenen komutanlar iktidarı ele geçirmek için büyük bir mücadele içerisine girmişlerdir ki bu komutanlar arasında cesareti ve kahramanlığı ile temayüz eden Mamay en önde gelenler arasında yer almıştır. Mamay, Özbek Han'ın torunlarından Avdul (Abdullah)'u han ilan ettirmiş ve onun adına hareket ederek Altın Orda'da duruma hâkim olmuştur (Nikonovskaya Letopis 1862: 233).

Altın Orda 1380’lere doğru gittikçe güç kaybederken, Moskova güçlenmeye başlamış ve bu güç Ruslara, Altın Orda'ya karşı harekete geçme vaktinin geldiğini hissettirmiştir. Nitekim Altın Orda'daki karışıkları dikkatlice takip eden Moskova Knyazı Dmitriy İvanoviç, Mamay’n tahakkümü altındaki Altın Orda ile bir gün mutlaka karşılaşmak zorunda kalacağını bildiğinden yönetimi altında bulunan bütün Rus Knyazlarını birleştirme çalışmalarına başlamışır. 1350 yılında doğan Dmitriy İvanoviç çok küçük yaşta 11 yaşında iken Moskova tahtına çıkmış, babası ve dedesi tarafından Moskova Knyazlığının kuvvetlendirilmesi yolunda başlatılan çalışmaları aynen devam ettirmiştir.

Moskova Knyazı Dmitriy'in en önemli hedefi o sırada Altın Orda Saray 
Hanı olan Murat'ın Moskova'yı zayıflatmak amacıyla Suzdallı Dmitriy Kostantinoviç'e verdiği Vladimir Knyazlığını almak, hem ticarette hem de Altın Orda ile mücadelede önemli rol oynayan İtil yolunu açarak Aşağı Novgorod'a kesin olarak hâkim olmak ve bu gaye ile Ryazan Knyazlığını elde etmek olmuştur.

Dmitriy'in karşısında en güçlü düşman olarak gördüğü Emir Mamay, kendisini iyi yetiştirerek, siyasî ve askerî alanda gösterdiği başarılar sayesinde etrafındakilerin güvenini kazanarak güç elde etmiştir. Mamay, bazı kaynaklara göre Altın Orda'nın Cuci sülalesinden gelen son hanı olan Berdibek'in kızı ile bazı kaynaklara göre de Canı-Bek'in kızı Sulu Haniş ile evlenmiştir (Kafalı 1976: 40, Yakubovskiy 1992: 117) ${ }^{1}$. Genel kanaat Berdibek'in kızı ile evlendiğidir. Bu evlilik sayesinde Berdi-Bek Han zamanında, Batı Deşt-i Kıpçak beylerinin beyi olmuştur (Kafalı 1976: 102). 1357-1359 yıllarında, yani Berdibek' in hayatta olduğu dönemde de kendisini "Beklyaribek" (Beylerbeyi) olarak adlandırarak kendi adına başka ülkelere elçiler göndermiştir. Mamay, Cengiz Han sülalesinden gelmediğinden han olamamış ve bu yüzden Alın Ordu hanlarının taht mücadelelerinde farklı adayları desteklemek zorunda kalmıştır. Ancak Rus yıllıkları Mamay'1 "Han" kudretine sahip olduğundan dolayı yanlış olarak "Han Mamay" şeklinde yazmışlardır. Yine yıllıklarda Mamay'ın oldukça dindar, gururlu ve kibirli bir kişiliğe sahip olduğu da ifade edilmiştir (Nikonovskaya Letopis X, 1897: 233-4).

Altın Orda’da çıkan karışıklıklar gerek Rusya gerekse Litvanya için elverişli bir durum yaratmıştır. Litvanya Knyazı Olgerd (1341-1377), Tatarlara karşı başarı kazanıp 1365 'te Kiyev'i almayı başarmısssa da Dmitriy İvanoviç ile uzlaşmaktan çekindiğinden Moskova Knyazlığını zayıflatmak amacıyla Mamay ile anlaşmayı tercih etmiştir. Dmitriy de Altın Orda'daki karışıklıktan istifade ederek Mamay'ın yardımından yararlanmayı denemiş, ancak Mamay ile Moskova arasındaki iyi ilişkiler her iki tarafın birbirlerinden şüphelenmeleri üzerine uzun süre devam edememiştir. Mamay, Moskova Knyazlığının kuvvet ve nüfûz bakımından büyümesinden korkarken, Dmitriy İvanoviç de Rusya’nın Tatar hâkimiyetinden kurtulmasında en büyük engellerden biri olarak Mamay'ı görmüştür. Mamay, Dmitriy İvanoviç'in Rusyàyı birleştirme siyasetine karşı Tver ve Ryazan knyazlarına baskı yapmış, ancak Tver knyazları 1375 yılında yaptıkları anlaşma gereğince 
ihtiyaç halinde asker gönderme sözü karşılığında Moskova Knyazlı̆̆ının hâkimiyetini tanımak zorunda kaldıklarından Mamay istediği sonucu alamamıştır (Yakubovskiy 1992: 123).

Rus Knyazılarının Altın Orda'ya verdikleri vergileri azaltmaya başlamalarından Mamay, Moskova’nın Tatarlarla savaşacağını anlamıştır. Bu anlayışı destekleyen uygulamalardan biri de Moskova Knyazı Dmitriy'in bir süredir Orda ile ilgisini kesmiş ve Mamay tarafından istenilen taleplere red cevabı vermiş olmasıdır. Moskova, Tatarlardan ya tam olarak kurtulmaya çalışacak ya da hiç olmazsa vassallık bağlarını gevşetmeyi deneyecekti. Mamay, bunun gerçekleşmemesi için Moskova ile bir savaş yapmaya ve knyazı zorla da olsa inkiyat altına almaya hazırlanmıştır. Bu savaşı yağma maksadı ile değil, Rusya’yı tam zayıflatmak veya tekrar hâkimiyeti altına almak amacı ile yapmak istemiştir. Bu amaçla 1378'de Aşağı Novgorod'a ve Moskova'ya bir sefer düzenlemiştir. Aşağı Novgorod'ı almasına rağmen Moskova'yı ele geçirememiştir. Dmitriy İvanoviç, Mamay tarafindan gönderilen Altın Orda Beyi Bigiç̧in askerlerini Oka Nehri'nin ilerisine atmıştır. Ruslarla Tatarlar arasında Voja Irmağı boyunda yapılan savaşta Ruslar kesin bir zafer kazanmışlardır. Tatarlar ise arkalarında çok sayıda ölü bırakarak kaçmışlardır (Nikonovskaya Letopis, XI 1897: 46).

Mamay, bu mağlubiyetin ancak büyük bir zafer ile unutulabileceğini düşünmüş ve o sırada yaşanılan siyasî hadiseler de onun lehine gelişme göstermiştir. Moskova knyazının güçlenmesini istemeyen Litvanya Knyazı Jagiello (Yagaylo) ${ }^{2}$ ona yardım edeceğine söz verdiği gibi Ryazan Knyazı Oleg de Mamay'a bağlılığını bildirmiştir. Bu bağlılı̆̆ın sebebi elbette Mamay’a karşı duyduğu sevgi değil, Altın Orda’ya karşı geldiği takdirde Tatarları karşısına alıp onların akınlarıyla karşılaşacağını iyi biliyor ve bundan korkuyor olmasıdır (Yakubovskiy 1992: 128-9).

\section{Kulikovo Savaşı ve Zaferi}

1380 yılında Mamay'ın büyük bir ordu toplayarak, Voronej yakınlarında bulunduğunu haber alan Dmitriy, bütün gücüyle karşı koymak için hazırlanmıştır. Ezeli rakibi Tver Knyazı Mihail de dâhil olmak üzere bütün Rus knyazlarına müracaat etmiştir. Kendisine tâbi Rostov, Yaroslavl ve Beloozero knyazlarından başka, Litvanya Knyazı Olgerd'in oğulları da Litvanya kıtaları ile yardıma gelmişlerdir. Daha önce de bahsettiğimiz gibi 
Tver Knyazlığı Moskova’nın hâkimiyetinde idi ve istenildiğinde askerî birlik göndermek zorundaydı. Dmitriy, bu zorunluluğu kendi knyazlığı için gurur verici olarak dillendirmiş, ama Şirokorad'ın ifadesi ile "Moskova için belki de en zor gününde bu şart yerine getirilmemiştir" (Şirokorad 2005: 173). Tver'in yanısıra, Novgorod ve Ryazan knyazları da yardım göndermemişler, ancak Mamay'ın tarafında da yer almamışlardır. Dmitriy bir yandan savaş için gerekli hazırlıkları yaparken; diğer taraftan Tatar tehlikesine karşı ortak bir Rus savunması oluşturmak gayesiyle Metropolit Kiprian'dan manevî yardım almıştır.

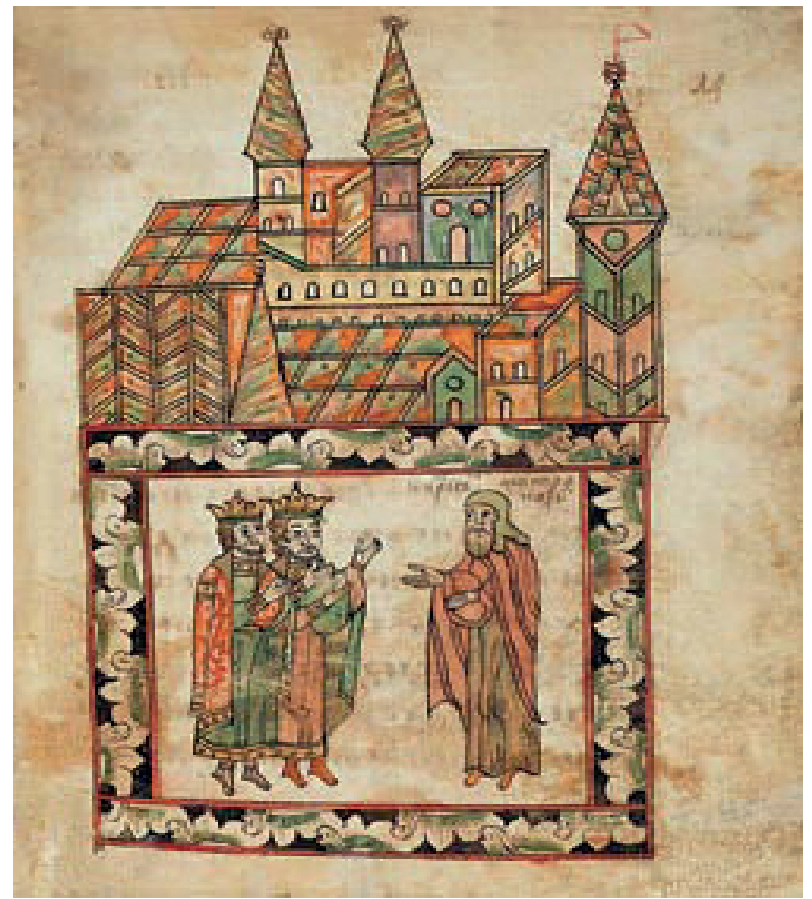

Resim 1. Metropolit Kiprian, Dmitriy ve Serpuhovlu Vladimir ile birlikte dua ederken (http://www.vokrugsveta.ru/telegraph/history/427/)

Rus Kilisesi'nin temsilcisi olarak çalışan Kiprian, Dmitriy'e sadece yardım etmekle kalmamış, aynı zamanda Rus knyazlarının Moskova etrafında toplanmaları için de çağrılarda bulunmuştur. Kaynaklarda her iki tarafın asker sayısı hakkında mübalağalı sayılar verilerek 150.000-300.000 arasında 
oldukları kaydedilmiştir. Sayının bu kadar abartılı verilmesinin nedeni elbette ki Rusların birleştiklerinde ne kadar büyük bir orduyu toplayabileceklerini ve Mamay'ın büyük ordusunu yenebileceklerini göstermek istemelerinden kaynaklanmıştır. Ancak bu konularda tarafsız olmaya çalışan Rus bilim adamları her iki tarafın ordusunun en fazla 30.000 askerden oluştuğu görüşündedirler ki aslında Mamay'ın Altın Orda’nın bir bölümünü yönettiğini düşünürsek bu sayıdan daha fazla bir asker toplaması da imkânsız görünmektedir (Şirokorad 2005: 172-173). Moskovàda Rus ylllıklarına göre 150.000 (?) kişilik ordu toplayan Dmitriy 31 Temmuz 1380'de Rus alaylarına Kolomna’da toplanmaları emrini vermiştir. Seferin manevî destekleyici ise Moskova yakınlarında kurulan Troitsko-Sergieevo Manastırı'nın başrahibi Sergius olmuştur. Sergius, Knyaz Dmitriy’i sefer için takdis etmiş, çok kan dökülmesi pahasına da olsa zaferi müjdelemiştir. Peresvet ve Oslebya adında iki savaşçı-kahraman rahibi onlarla birlikte gönderirken kendisi de Mamay’a karşı Kolomna'dan sefere çıkmak niyeti ile hareket etmiştir. Dmitriy sefere hazırlanırken yıllıkçıya göre tüccarlardan da yararlanmıştır ve onlardan Mamay'ın ordusu ve gücü hakkında bilgiler almıştır.

Dmitriy, Kolomna’dan güneye yönelmiş ve Oka’da Lopasna Irmağı ağzında karargâh kurmuştur. Timofey Vasilyeviç burada askerleri ile ona katılmıştır. Eylül'de Rus alayları Berezuy'a vardıklarında Dmitriy' in yanına bazı Litvanya knyazları da gelmişlerdir. Buradan yola çıkılmışve Don (Ten) vadisinde bulunan Kulikovo Ovasında ${ }^{3}$ Rusya’nın büyük düşmanı Mamay ile karşılaşıııışıır. Mamay Litvanya Knyazı Yagaylo'nun ordusu ile gelmesini beklemiş ama Yagaylo sözünde durmayarak kararlaştırılan zamanda oraya gitmemiştir. Aslında iki kardeşinin kendisine karşı isyan etmeleri ve bu kardeşlerinin daha sonra Moskova’yı desteklemek üzere kendi birlikleri ile Moskova ordusuna katılmaları yüzünden Mamay’a yardıma gidememiştir. Zira bu iki kardeşin tavsiyesi üzerine Moskova ordusu Mamay'ın Yagaylo ile birleşmesini önlemek için Don'u geçme kararı almıştır. Mamay daha fazla beklemeden 8 Eylül günü Kulikovo Ovasında Ruslar'la savaşa başlamıştır. Bundan sonrasını yıllıkçının ağzından dinleyelim:

Don’un Aşağısındaki Büyük Kanlı Savaş Hakkında

6888:1380: Yine bu yıl Tanrısız, kızgın, alçak Ordalı Mamay, bütün Kuman/Kıpçak ve Tatar topraklarından pek çok asker topladı. Bu orduya Frenkler, Çerkesler, Yaslar (Alanlar veya Aslar) 
da katıldılar. Hep birlikte Büyük Knyaz Dmitriy İvanoviç ve bütün Rus knyazlarının üzerine topraklarına gittiler. Aylardan Ağustos idi ve kendi Ordasından ayrılan Tatar ordusu Hristiyanlara ve Büyük Knyaz Dmitriy İvanoviç'e doğru harekete geçti. Bu alçaklar Müslüman idiler. Gaddar, canavar, hilekâr, namuzsuz, öfkeli Mamay, Büyük Knyaz Dmitriy’i, dostlarını, sevdiklerini ve diğer Rus knyazlarını İtil'in aşağısında yenmek için büyük bir güçle ilerledi ve Rus topraklarını esir almak istedi. Bütün bunları duyan büyük Knyaz Dmitriy İvanoviç, vatanını kurtarmak, kutsal kilise ve Hristiyanlık inancına inanan bütün müminler ve tüm Rus toprakları için büyük bir ordu toplayarak onların üzerine gitti. Bu sırada ona Mamay’ın Don'un dışına doğru gittiğini, burada toparlandığına ve Litvanya alaylarının Knyazları Yagaylo ile beraber yardıma gelmelerini beklediğine dair bir haber geldi. Büyük Knyaz Don'un dişına gitti ve temiz topraklarda büyük kötülükler oldu. Alçak Kuman/Kıpçak ve Tatar alayları temiz Nepryadva Nehri'nin ağzına gittiler.

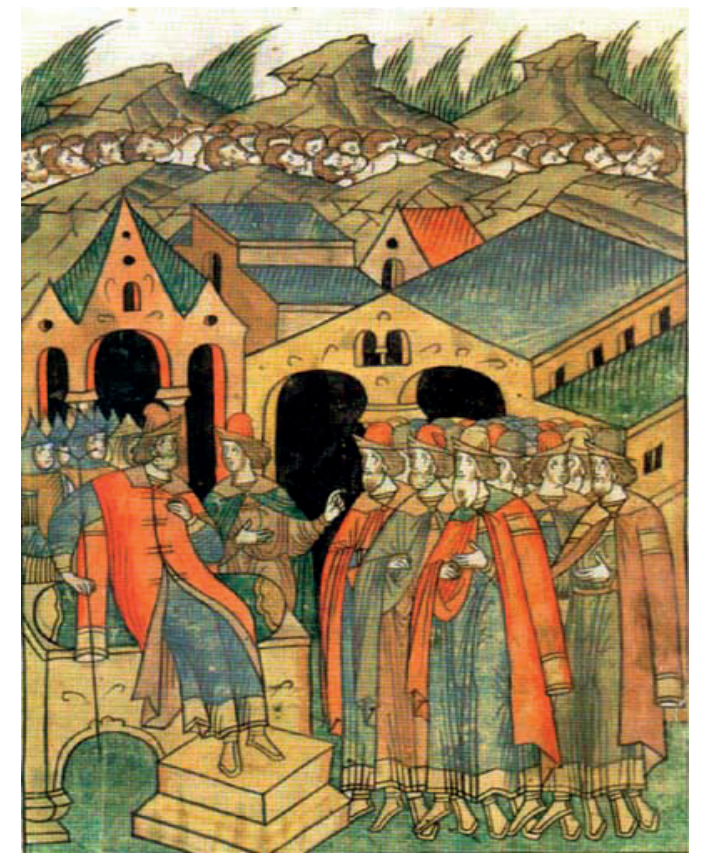

Resim 2. Mamay yakın adamaları ile görüşürken (http://hrono.ru/biograf/bio_m/mamai.php) 
Her iki taraf karşı karşıya geldiler ve savaş gerçekleşti. Savaş akşama kadar sürdü ve pek çok kötülük yaşandı. Ertesi gün her iki taraftan da sayısız asker öldü ve Tanrı Büyük Knyaz Dmitriy İvanoviç'e yardım etti. Mamay'ın kendisi ve geride kalan askerleri ise kaçtılar. Bizimkiler onlarla da çok savaştılar ve kaçanları affetmediler. Ancak Tanrı Agaryanlar (Müslümanlar)'ın çocuklarını büyük bir güçle donatmıştı ve onlar kaçmayı başardılar. Ama ellerinde hiçbir şey kalmadı, silahlarının çoğunu kaybettiler, ellerinde kalanları da nehirde düşürdüler. Onları nehre kadar kılıçları ile kovaladılar ve onlardan pek çoğunu öldürdüler, geride kalanların büyük bir kısmı da nehirde boğuldu.

Tanrı'nın öfkesi yabancı, başka bir kabileden olanları sardı ve bu yaratıklar bu yüzden korktular. Mamay küçük bir asker grubu ile kendi Tatar topraklarına döndü. Bu kanlı savaş Kutsal Meryam Ana’nın doğum günü olan Cumartesi öğlene doğru oldu. Mamay’ı elinden kaçıran knyazlar arasında Belarus Knyazı Födor (Feodor) Romanoviç ve oğlu Knyaz İvan Födoroviç, Semen Mihayloviç, Mikula Vasilyeviç, Mihaylo İvanoviç, Akinfoviç, Andrey Sekizov, Timofiy Boluy, Mihaylo Brenkov, Lev Morozov, Semen Melik, Aleksandr Perevest gibi pek çok knyaz, Dmitriy İvanoviç ve diğer Rus knyazları, voyvodoları, boyarları, ricalden ileri gelenler ve Rus alaylarından geride kalanlar ile bu ateşte kalanlar Tanrı'ya şükrettiler. Kendi drujinalarını yabancı bir soya karşı sağlam bir şekilde savaştıran, onları durdurabildiren, erkekçe ve cesaretle savaşmalarını sağlayan Tanrı'yı Hıristiyanlık adına methettiler ve buradan Moskova'ya kendi vatanlarına büyük bir zaferle, düşmanlarını yenmiş olarak döndüler. Ordu bu savaştan zaferin yanında büyük bir ganimet de elde etti: beraberlerinde hayvan sürüsü, at ve deve ile sayısız silah ve eşya getirdiler. Ryazan Knyazı Oleg bunları duyunca kendi güçlerini Mamay'ın yardımına gönderdi, kendisi ise nehirdeki köprüde bekledi.

Büyük Knyaz Dmitriy, Oleg'in köprüde olduğunu öğrenince ordusunu üzerine gönderdi. Bunun üzerine Ryazan Knyazı aniden onun üzerine doğru yöneldi. Büyük Knyaz onu yendi ve Knyaz Oleg ise kendi topraklarını yitirdi. Hanımı, çocukları, boyarları 
ve fikirdaşları ile kaçtı. Ailesinin ona ordusunu göndermemesi ve kendi tarafında yer alarak savaş için sıraya girmesi için yalvardığını öğrendiğinde Büyük Knyaz bütün bunları umursamadı, ama bizzat kendisi üzerine gitmeyip Rus topraklarına geri dönerken genel valisini üzerine gönderdi. ${ }^{4}$ (Troitskaya Letopis 1950: 419-421)

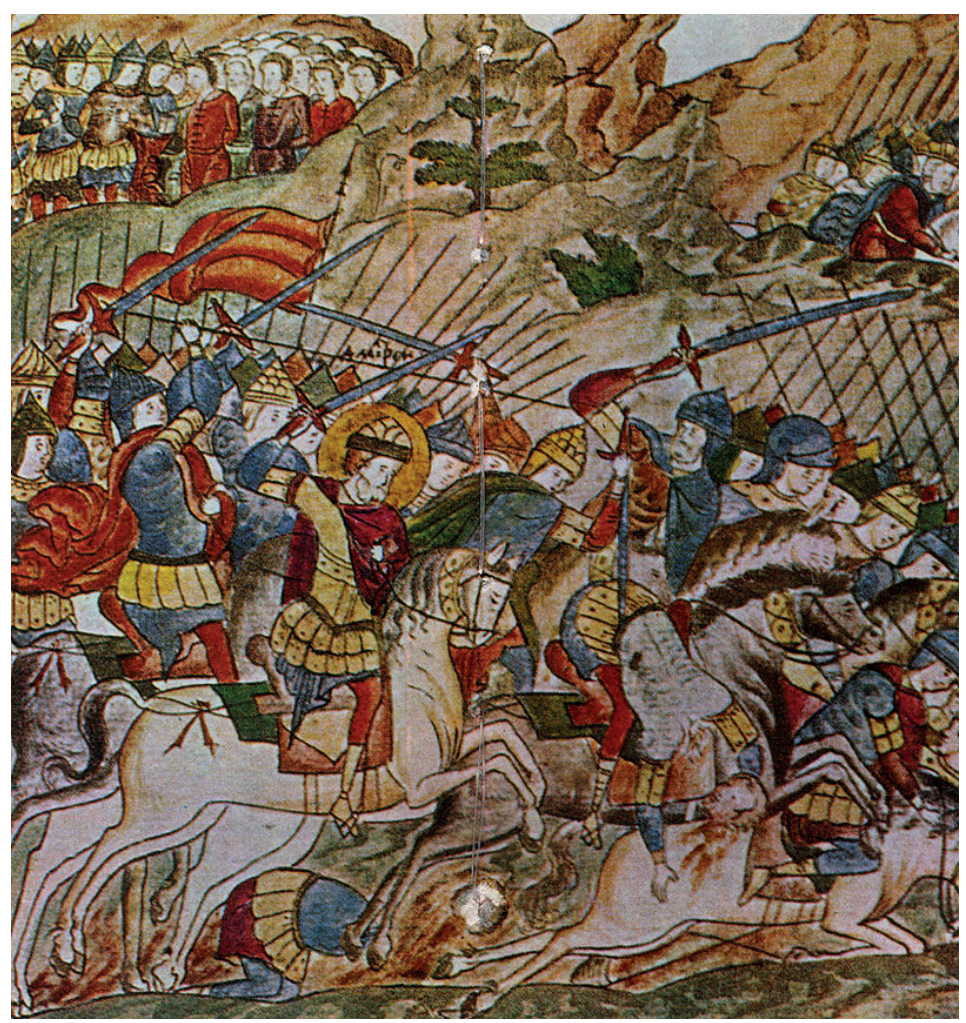

Resim 3. Kulikovo Savaşı (http://konevodstvo.su/books)

Yıllıkçının ifadelerinden de anlaşıldığı üzere öğlene doğru başlayıp akşama kadar devam eden mücadelede başlarda Mamay'ın ordusu üstün gelmişse de daha sonra durumu lehine döndürememiştir. Mamay sahip olduğu çok sayıdaki askere güvenerek savaşa girmiş, ancak hesap edemediği uzun yıllardır böyle bir günü bekleyen Dmitriy'in onların nasıl hareket edeceklerini, sayılarını, ne kadar ve hangi silahlar ile geldiklerine dair en ince detaylı bilgilere dahi sahip olduğudur. Ayrıca Dmitriy o sırada her 
ihtimale karşı ordusunun bir kısmını pusuya yatırarak durumun aleyhlerine dönmesi hâlinde savaşa katılmaları emrini de vermiştir ki askerlerinin "biçilmiş ot gibi" yerde yattığını görünce de bu birlikleri savaşa sokarak, Mamay'ın ücretli askerlerine doğru harekete geçirtmiştir. Bu ücretli askerlerin Dmitriy'in ordusuna yeni askerlerin katıldığını zannederek kaçışmaya başlamaları savaşın kırılma anının yaşanmasını sebep olmuştur. Büyük bir mağlubiyet yaşayan Mamay, geride kalan askerleri ile kaçmaya çalışırken, büyük kayıplar veren Ruslar onları tâkip edememişlerdir. Her iki tarafın kaybı noktasında kesin bilgimiz olmamakla beraber Rusların birçok knyaz ve boyarını kaybettiğini, yıllıkta cesetlerin 10 kilometre öteden görüldüğü şeklindeki kaydından anlamaktayız (Yücel 2008: 247).

Zafer sonrasında pek çok rivayet ortaya çıkmıştır ki bunlardan biri de Knyaz Dmitriy'in savaş öncesinde zaferin kendilerinin olacağına dair bir rüya gördügüdür. Bu rüyaya göre Tatar ordugâhına bir karanlık çökmüş ve daha sonra kurtların ve kargaların sesleri duyulmuştur. Bundan sonra Rus odugâhının bulunduğu yerde gökyüzünde 1şıllar görünmüş ve gökyüzünü aydınlatan bu ışıkları Dmitriy, zaferi kendilerinin kazanacağına ancak bunun çok pahalıya mal olacağına yormuştur (Azbelev 2011, Erişim Tarihi 26.01.2017).

Knyaz Dmitriy, Rus tarihine adını altın harfler ile yazdıracak olan Kulikovo'da gerçekleştirdiği bu muhteşem zaferin ardından büyük şenlikler düzenleyerek Moskovàya dönmüştür. $O$ güne kadar Ruslar’a büyük korkular yaşatan Tatarların bu yenilgileri Rus halkı üzerinde büyük bir etki yapmış ve maneviyatlarını son derece yükseltmiştir. Bu zafer Ruslar'a 156 yıldır tahakkümleri altında bulundukları Tatarları yenebileceklerini gösterirken, Moskova Knyazlığı ile Knyaz Dmitriy İvanoviç̧in de otoritesini yükseltmiş ve kendisine "Donskoy: Don Zaferi Kahramanı" unvanı verilmesini sağlamıştır.

$\mathrm{Bu}$ zafer Rus tarihinde Altın Orda hâkimiyetinden kurtuluşlarının ilk adımı olarak kabul görmüş, 1848 yılında Rusya hükümeti bu zaferi ebedileştirmek gayesi ile savaşın yaşandığı alana bir anıt diktirmiştir. Yine zaferin yaşandığı bugün yani 8 Eylül'ün "Rus Ordusunun Onur Günü” olarak kutlanmasına karar verilmiştir. 


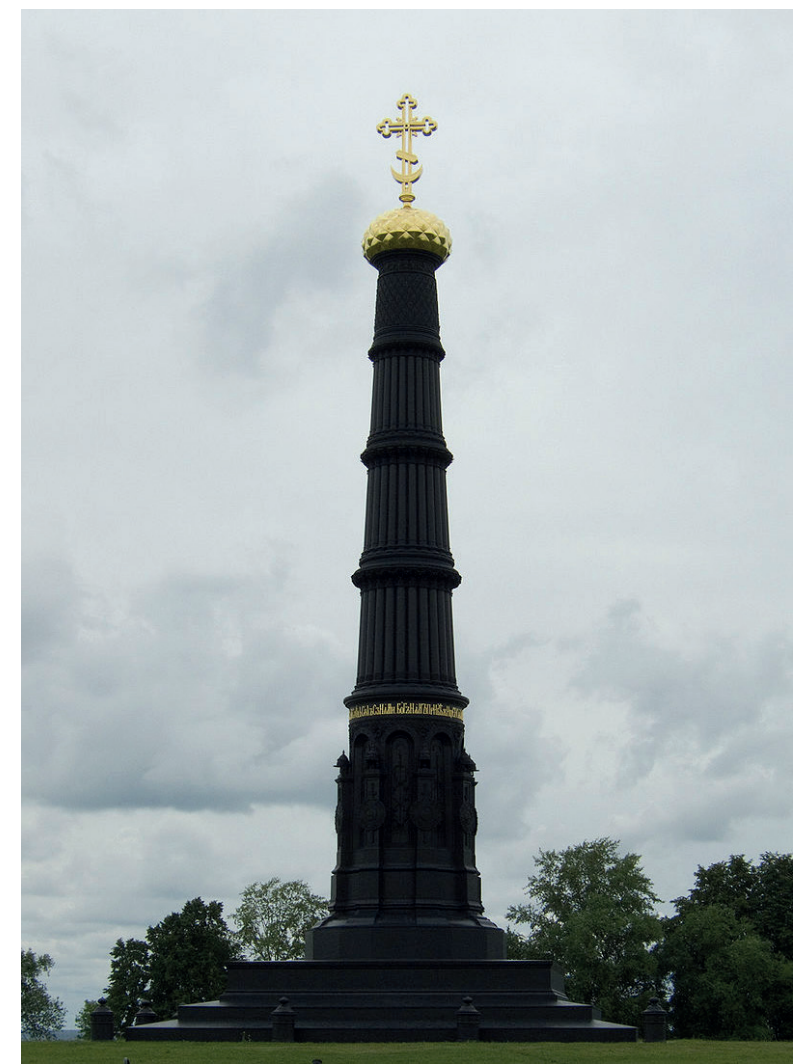

Resim 4. 1848'de Akademisyen A.P. Brulov'un teklifi ile dikilen Kulikovo Zaferini Ebedileştiren Ant 5 (http://photo-drive.ru/wordpress/kulikovskayabitva)

Kulikovo Savaşı'nı bir "tesadüf” olarak kabul eden ve Rusların çok güçlendikleri için değil de Alıı Orda’nın fetret dönemini yaşadığ 1 için galip geldiği de ileri sürülen görüşler arasındadır (Kamalov 2009: 102). Elbette ki Dmitriy bu zaferi Altın Orda bir duraklama dönemine girdiği için yaşamıştır ancak unutmamak gerekir ki yüzelliyıldan fazla bir zamandır hâkimiyeti altında bulundukları bu devleti çok iyi tanıma fırsatını bularak ona karşı nasıl savaşacaklarını da anlamışlardır. Bu savaşın öncesinde yaşanan olaylara baktığımızda zaferi bir tesadüf olarak değerlendirmekten ziyade Rusların Altın Orda'yı ne kadar iyi tâkip ettiklerini ve onu ancak ona denk bir güçle yenebileceklerine olan inançlarının bu başarıyı getirdiğini ifade edebiliriz. 


\section{Zadonşina Destanı}

$\mathrm{Bu}$ zaferden çok kısa süre sonra bu sefer ve zafer hakkında destanlar yazılmıştır ki bunlardan Mamay Savaşı Hakkında Hikâye, Rus Çarı Büyük Knyaz Dmitriy İvanoviçin Hayatı ve Ölümü Hakkında Hikâye ile Zadonşina en çok yayılanları olmuştur. Her üç eserde Kulikovo Savaşının tarihi açıdan aydınlatılmasında Rus tarihçilerinin başvurdukları ve esas aldıkları temel kaynaklar arasında yıllıklardan sonra en önemli kaynak olma özelliğini taşımaktadırlar.

Çalışmamızın konusunu oluşturan Zadonşina Destanı hakkında bugüne kadar Rus ilim âleminde pek çok çalışma yapılmış ve destanın başta adı, yazarı olmak üzere nerede nasıl yazıldığı ile yazılış tarihi üzerine pek çok görüş ileri sürülmüştür. Destana adını veren Zadonşina kelimesi üzerinde de yine birçok araştırma yapılmıştır ki bu kelime Türkçe "Don Nehri Ötesinde, Don'un Arkasında, Ardında Gerçekleşen Olaylar" anlamına gelmektedir. Rus Knyazlıkları ile Altın Orda arasında yaşanan hadiseleri anlatan bu lirik-epik tarzdaki destan bazı belgelerde söz, nutuk, methiye, şikâyet veya yakınma olarak da adlandırılmaktadır (Dmitriyev 1988: 345-352).

Rus ilim adamları öncelikle Zadonşina kelimesinin destana nasıl ad olarak verildiğini araştırmışlardır ki Rusya’da yıllıklar ve destanlar konusunda öne çıkan ilim adamlarından birisi olan D.S. Lihaçev'e göre Zadonşina kelimesi eserin asıl başlığı olmaktan ziyade başlıkta yer alan bir kelimedir ve eserin atıfta bulunduğu olayları ifade etmektedir. Dolayısıyla destanın başlığının çevirisi şu şekilde olmalıdır: “...İhtiyar Ryazanl Sofoniinin yazısı kutsal Tanrım. Büyük Knez Efendimiz Dmitriy İvanoviçin ve Kardeşi Vladimir Andreeviç̧in Don Ötesi Seferi”. Yine Lihaçev’a göre zadonşina sözcüğü Dmitriy İvanoviç ve kardeşinin Don Nehri ötesine yaptıkları seferle ilgili bir grup tarihi olaylar anlamına gelmektedir ve 1380 yllında gerçekleşen olayları kapsayan, halkın kendiliğinden oluşturduğu bir sözcüktür (Lihaçev 1966: 474-75).

Destanı kimin yazdığına dair farklı görüşler ileri sürülmüşse de destanı yazanın Ryazanlı olduğu genel kabul görmüş ve yazarı hakkında iki görüşs̈ne çıkmıştır. Bunlardan biri Ryazan'lı Sofonii (Ryazanets Sofonii) (Dmitriyev 1988: 347-348, Lavrentyev: 2015: 320)'dir ve o sadece 1380 yllındaki bu sefere katılmamış, Mamay'ın düşmanı olarak Dmitriy İvanoviç'in yaptığı 
diğer seferlere de katılmıştır. Bu yüzden de araştırmacılardan bazıları Ryazan’lı Sofonii'yi, bizzat destanın yazarı olarak kabul etmişler (Lavrentyev: 2015: 320) ve destanı yazarken destan metninin içerisine kendi ismini koyduğunu belirterek, onun İgor Bölüğü Destanı ile Mamay Destanı'nı da gördüğünü öne sürmüşlerdir. Zadonşina’nın bilinen altı nüshasından ikisinde Ryazanlı Sofonii, "yaşlı" olarak verilirken, diğer nüshalarda ise ismi Sofoniia/Sofoni olarak verilmektedir (Pamyatniki 1998: 89, 97, 113). Tver Yıllığında ise Sofoni, "Ryazanlı-Buryanskili boyar" olarak geçmektedir. (PSRL VI: 440); diğer görüşe göre ise destanın yazarı destanda sürekli Dmitriy İvanoviç’in yanında yer alan ve iki manevî kardeşinden biri olan Serpuhov bölgesinin knyazı Vladimir Andreeviç่tir ve bu görüşün en önemli savunucusu da Solovyev'dir (Solovyev 1958: 193). Kulikovo Savaşı'nı anlatan yıllıklarda da her ikisi daima birlikte anılırlarken, Mamay Savaşı Hakkında Hikâye’nin pek çok varyantında Dmitri İvanoviç tek başına gösterilmektedir (Lavrentyev 2015: 321). XV. yy' in 30'lu yıllarında yazılan Novgorod-Sofiyski Yıllığı'nın bu savaş hakkındaki kaydını esas alan ilim adamlarına göre bu nüsha Kulikovo hakkında yazılan en eski nüsha olma özelliğini taşımaktadır ki bunun protografı (antikgraf) XIV. yüzyılın 90’lı yıllarına doğru yazılmıştır (Pamyatniki 1998: 47). Bu yüzdendir ki büyük bir ihtimalle hem Zadonşina’nın yazılma tarihi bu tarihe dayandırılmış hem de iki kardeşin isimleri rastgele destana konulmamışır (Lavrentyev 2015: 321).

Destanın yazıya geçiriliş tarihi net olarak ortaya konulamamışsa da genel kanaat XV. yüzyılda yazıldığıdır. Destanın günümüze 6 nüshası ulaşmıştır ve bunlardan en eskisi Kiril-Beloozero № 9/108 Manastırı nüshasıdır. Bu nüshanın ilk kopyasının XV. yüzyılın 70-80'li yıllarında Kiril-Beloozero Manastırı rahiplerinden Yefrosin tarafından yapıldığı düşünülmektedir.

Diğer nüshaları ise şunlardır:

1) Undol Nüshası № 632 (XVI. yüzyıl)

2) Jdanov Nüshası № 1.4.1 (XVII. yüzyıl)

3) Birinci Tarihi Müze Nüshası № 2060 (XVI. yüzyıl)

4) İkinci Tarihi Müze Nüshası № 3045 (XV. yüzyılın sonu XVII. yüzyılın başı)

5) Sinodal Nüshası № 790 (XVI. yüzyıl) 
Destan ilk defa 1852 yılında V. M. Undolskiy'in redaksiyonundan geçerek yayınlanmıştır.

Bu destanın bir diğer önemli özelliği de Rusların en eski destanları olarak bilinen 'Slovo o Polku İgoreve: İgor Bölüğ̈̈ Destanı” ile olan benzerliğidir. Bu benzerlik iki eserden hangisinin daha eski ve orijinal olduğunun tartışılmasını da beraberinde getirmiştir. Özellikle XIX. yüzyılda Fransız Slavist Luis Léger XVIII. yüzyılda yazılan Zadonşina Destanı’nın, İgor Bölüğü Destanı esas alınarak yazıldığını ileri sürmüş ve ona A. Mazon, A.A. Zimin, K. Trost, O. Süleymanov gibi ilim adamları da katılmışlardır. Bu ilim adamlarına göre Zadonşina'yı yazan kişi bazı mitolojik unsurları, cümleleri, hadiseleri anlatış uslûbunu ve kullandığı kelimelerden bazılarını İgor Bölüğü Destanı'ndan almıştır. Bilindiği üzere İgor Bölüğü Destanı 1185 yılında yaşanan Kuman/ Kıpçak-Rus Savaşı'nı anlatmaktadır.

Çalışmamızda Zadonşina Destanının Kiril-Beloozero nüshasının Lihaçev neşri (Lihaçev 1981: 184-200) kullanılmıştır ve bu nüshanın Türkçe metni şu şekildedir:

\section{Büyük Knyazz Dmitriy İvanoviç ve kardeşi KnyazVladimir Andreeviç'in, düşmanları Emir Mamay'ı nasıl yendiklerine dair hikâye}

Büyük Knyaz Dmitriy İvanoviç, kardeşi Knez Vladimir Andreeviç, askerleri ile Mikula Vasilyeviç'e bir ziyafet vererek şöyle dedi: “Kardeşlerim Mamay'ın Don yakınlarında olduğuna ve Rusya'ya gelerek bizim Zaleski topraklarına ${ }^{6}$ gitmek istediğine dair haber geldi”.

Haydi kardeşlerim! Ortodoks Rus halkının geldiği Nuh'un oğlu Yafes’en miras kalan kuzey tarafa doğru gidelim. Kiev Dağları'na kadar gidip, bütün Rus topraklarına ve ünlü Dinyeper (Özü)'e bakalım. Daha sonra doğudaki topraklara ki Nuh'un oğlu Sam'dan gelen (Sama düşen) Hinova ${ }^{7}$-Pagan Tatarları ve Kâfirlere ${ }^{8}$ biraz bakalım. Burada bir yerde Nuh'un kabilelerinin yendiği Kayala Nehri vardır. Bu Rus topraklarına dalgalar hâlinde üzüntü getirdi; Kalka Savaşı'ndan Mamay’ın yenilgisine kadar keder ve üzüntü içerisinde - knyazlar, boyarlar, evlerinde bıraktıkları hanımlarını, çocuklarını ve tüm zenginlik ve servetlerini yani sahip oldukları her şeyi kaybeden insanlar, şan ve şeref için hizmet edip, barış ve onur için çalışanlar, Hristiyan inancı ve Rus toprakları için canlarını verenler kendi oğullarını ağlayarak hatırliyorlar. 
Rus topraklarının evlatları, kardeşlerim ve dostlarım! Rus topraklarının eskiliğini ve merhametini kitaplardaki efsanelerde yazanlar, Büyük Knyaz Dmitriy ve kardeşi Knyaz Vladimir Andreeviç’in merhametini de övgüyle yazacaklardır.

Bir araya gelerek hep birlikte, cümlelerimizi şöyle kuralım, Sam’ın hissesine düşen doğu ülkelerine, mührümüzü atarak Rus topraklarını sevindirelim ve övgüye değer Büyük Knyaz Dmitriy İvanoviç ve kardeşi Knyaz Vladimir Andreeviç’in Mamay karşısında aldığı zaferi övelim! Ve şöyle diyelim:

Kardeşlerim, Kutsal Büyük Kiyev Knyazı Vladimir'in torunları olan Büyük Knyaz Dmitriy İvanoviç ve kardeşi Knyaz Vladimir Andreeviç̧in seferi hakkındaki bu hikâye aslında bizi daha fazla yüceltiyor. Yaptıkları işler ve olup-bitenler hakkında konuşmaya başlayalım... Çok eski günlerde Kiyev'de bulunan yetenekli guslyar ${ }^{9}$ ile övgü dolu kâhin Boyan' $1^{10}$ hatırlayalım. Aslında kâhin Boyảnın hızlı ve güçlü parmaklarından Rus knyazlarının -Birinci meşhur Kiyev Knyazı İgor Rurikoviç, ikinci Büyük Kiev Knyazı Vladimir Svyatoslaviç ve üçüncü Büyük Kiyev Knyazı Yaroslav Vladimiroviç’in zaferlerinin şarkıları ve dizeleri çıktı.

Ben Ryazanlı Sofonii, Kutsal Büyük Kiyev Knyazı Vladimir'in torunları Büyük Knyaz Dmitriy İvanoviç ve kardeşi Vladimir Andreeviç’ in guslyarları çalarken çıkardıkları sesleri ve övgü dolu şarkılarını hatırlıyorum. Rus knyazları Hristiyan inancının amellerini azimle, sebatla yerine getiriyorlar, tamamliyorlar!

Kalka Savaşından Mamay Zaferine kadar yüzaltmış yıl geçti.

Ve böylece Büyük Knyaz Dmitriy İvanoviç ve kardeşi Knyaz Vladimir Andreeviç, Tanrı'ya ve onun temiz annesine dûa ederek, kendi güçlerini ve akıllarını sağlamlaştırıp, kalplerini cesaretle ve savaşçı bir ruhla dolduklarında, Rus topraklarının cesur alaylarını ve büyükdedesi Büyük Knyaz Vladimir’i hatırlayarak yola çıtılar.

Şan ve şöhrete sahip Büyük Knyaz Dmitriy İvanoviç ve kardeşi Knyaz Vladimir Andreeviç güçlü Moskova şehrinden sevinç içerisinde mutlulukla mavi göklerde süzülerek yükselen ve uçan çayır kuşları ile yaz kuşlarına bakıyorlar! Sanki fırtına Kuman/Kıpçak bölgesindeki Zlesskiy topraklarından bir şahin getirdi! Bütün Rus toprakları boyunca şan ve şöhret sesleri çınlıyor: Moskova’da atlar kişniyor, Kolomna'da ${ }^{11}$ davullar 
çalıyor, Serpuhov'da ${ }^{12}$ davullar dövülüyor, Büyük nehir Don'un kıyısında Rus bayrakları dalgalanıyor.

Gece Büyük Novgorod'da çanlar çalıyor, Novgorod'daki erkekler Kutsal Sofya Kilisesi'nde toplanarak şöyle dediler: "Kardeşlerim Büyük Knyaz Dmitriy İvanoviç'i kurtarmak bize düşmez mi?" Bu sözlerden hemen sonra artık kartal gibi olan ağızlar konuşmadı. Kartallar uçmadı- Büyük Novgorod'da oturanlar yanlarında yedi bin asker ile Büyük Knyaz Dmitriy İvanoviç ve kardeşi Knyaz Vladimir Andreeviç’e yardım etmek için gittiler.

Görkemli Moskova şehrinde bütün Rus knyazları toplandılar ve şöyle dediler:

“Don Nehri'nin kenarında Çurov ve Mihail arasından bulunan Meç Nehrinde ${ }^{13}$ bütün hayatı boyunca kazandığı şöhretini bize bırakmak isteyen pis Tatarların emiri duruyor."

Ve Büyük Knyaz Dmitriy İvanoviç şöyle dedi:

"Kardeşim, Knyaz Vladimir Andreeviç, oraya gidelim, hayatımızı şereflendirelim, yaşlıların anlattıkları toprakları görelim, gençlere ise hatırlatalım! Cesaretimizi gösterelim, ıristiyan inancı ve Rus toprakları için Don'da kanımızı aktıtalım!"

Ve Bütün Knyazlar, Dmitriy İvanoviç’e şöyle dediler: "Kardeşler ve Rus knyazları, bizler Büyük Kiyev Knyazı Vladimir’in ocağından değilmiyiz! Biz gönlümüzde ne şahin ne doğan ne aladoğan ne sungur ne karakarga ne de bu alçak Mamay'ın korkusunun doğmasına izin vermeyiz!”.

Bülbüller şakıyor, yaz kuşları ötüyor, Büyük Knyaz Dmitriy İvanoviç ve kardeşi Knyaz Vladimir Andreeviç, Litvanya topraklarından gelen Olgerdoviç kardeşler: Andrey ve kardeşi Dmitriy ile Volinli Dmitriy için öten, şarkılar söyleyen bülbülleri - ki Litvanya’nın cesaretli oğullarını, eski zamanların akdoğanı ve şöhretli komutanlarını, trampet sesleri altında kundaklananları, miğferlerine özenle bakanları, onları (hayatlarının sonuna kadar) besleyen mızraklar ile Litvanya topraklarını keskin bıçakla besleyenleri dinliyoruz!

Andrey Olgerdoviç kardeşine şöyle dedi:

“Kardeşim Dmitriy biz seninle Oleg’in oğulları, Gediminov (Edimantov)'un torunları ve Sokolomendov'un ${ }^{14}$ torunlarının torunu olarak iki kardeşiz. 
Kardeşler, Litvanya’ nın cesur yürekli sevgili beyleri, kendilerinin hızlı atlarına binenler ve Don'a hızlı bir şekilde göz atanlar, Don'dan miğferlerine su dolduranlar, Litvanya kılıçlarımızı Tatar miğferlerinde, Alman mızraklarını ise Müslümanların üzerinde deneyeceğiz!”

Ve Dmitriy ona şöyle dedi: "Kardeşim Andrey, (ben) Dmitriy İvanoviç’in hataları için değil ama Hristiyan inancı ve Rus toprakları için hayatımızı vermeye değmez mi! Kardeşim artık gör Moskova’nın üzerinde gök gürüldüyor ve taş taş üstünde kalmayacak. Kardeşim, Büyük Knyaz Dmitriy İvanoviç’in güçlü ordusundan ses yok, gök gürlemiyor, Rus altın yaldızlı silahları ve zırhlı takımları kurtlanmış (eskimiş) kalkanları ile sadece babayiğitler gürlüyorlar. Kardeşim Andrey, hızla atını eyerle, benimki hazırönceden seninki de eyerlensin. Kardeşim el değmemiş, bakir topraklara gidelim ve kendi alaylarımızla ve bizimle beraber ne kadar cesur Litvanya askeri varsa ki bizimle beraber 7 bin zırhlı cesur Litvanya askeri var birlikte gösteri yapalım.

İşte kardeşlerim denizden Don ve Dinyeper'in ağzına doğru güçlü esen rüzgârlar, Rus topraklarına kara uğursuz bulutlar getirdiler; bir taraftan ortalığa kanlı gök parıltısı yayılırken, diğer taraftan mavi renkte yıldırımlar çakıyor. Don ve Dinyeper arasındaki Nepryadva Nehri'nde gürültü ile gök gürültüsü birbirine karışıyor, Nepryadva Nehri'nde kanlar yok oluyor, Kulikovo bozkırlarını insan cesetleri kaplıyor.

Artık Don ve Dinyeper arasında Kuman/Kıpçaklar at arabalarını gıcırdatarak Rus topraklarına doğru gidiyorlar! Gri kurtlar uluyarak Don ve Dinyeper' in ağzındaki Meça Nehri'nden koşarak kaçıyorlar ve bir an önce yine Rus topraklarına gitmek istiyorlar. Alçak Tatarlar bütün Rus topraklarında savaşmak için gelmek istediklerinde henüz gri kurtlar (Mamay'in askerleri) yoktular.

Önceleri kazlar ötüyor, kuğular kanatlarını çırpıyorlardı. Ancak Alçak Mamay, kendi savaş̧̧larına açtığı yoldan Rus topraklarına geldiğinde ne kazlar ötebildiler ne de kuğular kanatlarını çırpabildiler. Artık bulutların altında uçan kanatlı kuşlar ölümü bekliyorlar, kargalar ve alacakargalar dinlenmeden sürekli gaklıyorlar, kartallar çığlık atıyor, kurtlar şiddetli uluyor, tilkiler kaçışıyor ve kemiklerin sesleri duyuluyor.

Rus toprakları, şimdi Kral Süleyman zamanında olduğu gibi oldu. 
Zaten sağlam Moskova şehrinden şahinler, sungurlar, altın kundaklara sarılmış Beloozerolu ${ }^{15}$ aladoğanlar yırtınarak, ipek yolunu kapatarak, mavi gökyüzünde şaha kalkarak, hızlı akan Don'da alıı çanın seslerini duymak, kazların ve kuğuların sayısız sürülerini vurmak istiyorlar, kahraman ve cesur Rus alayları büyük bir güce sahip alçak Mamay'ı yok etmek istiyorlar.

Büyük Knyaz Dmitriy İvanoviç, Tanrı’ya ve onun temiz annesine dua ederek, altın üzengili bronz atına binerek kılıcını sağ eline aldı. Güneş doğudan parlayıp yol gösterdiğinde Boris ve Gleb ${ }^{16}$ onların başarılı olmaları için dûa ettiler.

Tan ağırırken, bu uğultu ve gürültü nereden çıktı? Knyaz Vladimir Andreeviç alaylarını yerleştirdi ve büyük Don'a doğru harekete geçirdi. Ağabeyi Büyük Knyaz Dmitriy İvanoviç ona dûa ederek şöyle dedi: "Kardeşim! Rus bozkırlarını çiğneyen ve yurdumuzu elimizden alan bu pis Tatarların hâkimiyetine girmeyelim!"

Büyük Knyaz Dmitriy İvanoviç ona şöyle söyledi: "Kardeşim Vladimir Andreeviç! Biz seninle Büyük Kiev Knyazı Vladimir’in torunları olan iki kardeşiz, voyvodolar bize 70 boyar gönderdiler, ayrıca yürekli Beloozero Knyazı Fedor Semenoviç ve Semen Mihayloviç, Mikula Vasilyeviç, Volinli Dmitriy, Timofey Volyeviç, Andrey Serkizoviç, Mihail İvanoviç alayları ile birlikte toplam üçü̈zbin cesur asker geldiler. Boyarlar bize ümit bağladılar, drujinanın cesareti ise bugüne kadar denenmiş, altımızda bronz atlar, altından yapılmış silâh ve zırhlar, Çerkes miğferler, Moskova yapımı kalkanlar, Alman mızraklar, İtalyan hançerler ve demir kılıçlar olduğunda onlar bilinen yoldan, vazgeçmemek üzere geçtiler ve onların hepsi bir olup Rus toprakları ve Hristiyan inancı için başlarını vermeye hazırlandılar. Dalgalanan bayraklar, kendilerine ve adlarına şeref, onur ve ün kazandırmak isteyen askerler için hazırdılar".

Artık şahinler, aksungunlar ve Beloozerolu aladoğanlar Don'u almak için hızlı uçtular ve sayısız kuğu ve kaz sürülerini vurdular. Bunlar ne gerçek şahin ne de gerçek akdoğan idiler, -Rus knyazları Tatar gücünü kırmak için aniden geldiler. Kulikovo bozkırlarındaki Nepryadva Nehri'nde Kuman/ Kıpçak miğfeleri, demirden kılıçlar gümbürdeyerek kızgın mızraklar ile Tatar zırhlarını mahvettiler.

Kara toprağın altı Tatar topraklarının altı gibi kemiklerle örtüldü, kanları 
su gibi toprağa aktı. Bu güçlü ordu birleşerek hep beraber tepeleri, çayırları, nehirleri, akarsuları ve gölleri ayakları altında ezerek bulandırdılar. Div, Rus topraklarına kokunç toprağı dinleyin diye bağırdı. Şöhretleri Demir Kapılara $^{17}$, Ürgenç, Roma'ya deniz boyunca Kefe'ye, Tırnova’ya oradan İstanbul'a ulaştı ve Rus knyazlarını övdüler. Ruslar Kulikovo bozkırlarındaki Nepryadva Nehri’nde Tatar ordularını büyük bir yenilgiye uğrattılar.

Bu topraklarda korkunç-uğursuz bulutlar bir araya geldiler ve sürekli, ara vermeden gögü gürüldeterek yıldırımlar düşürdüler. Aslında alçak Tatarların büyük suçlarının cezasını Rusların evlatları çektiler. Altın zırhlar ışıldadı, Rus knyazlarının demirden kılıçları ile Kuman/Kıpçak miğferlerinin sesleri gürledi.

Tanrının Kutsal Annesi (Meryem Ana)'nın doğduğu gün olan cumartesi günü sabahtan öğlene kadar savaştılar.

Don yakınlarındaki Kulikovo bozkırlarında yeniden kaleler çoğalmadı. Büyük Knyaz Dmitriy İvanoviç’in voyvodaları, boyarları, saygıdeğer Rus knyazları, Büyük Don'un yakınlarında bu defa bu kalelerde ölmediler. Bu kez pis Tatarlar Beloozero Knyazı, Fedor Semenoviç, Semen Mihayloviç, Timofey Volyeviç, Mukila Vasilyeviç, Andrey Serkizoviç, Mihail İvanoviç ve onlara ait daha pek çok asker tarafından mahvedildiler.

Rahip Aleksandr Peresvet ${ }^{18}$ ve Buryanlı Boyarlar ${ }^{19}$ buraya adaleti getirdiler. Ve aydınlığın temsilcisi rahip Büyük Knyaz Dmitriy İvanoviç'e şöyle dedi. "Alçak Tatarlara esir düşmektense bizim için ölmek daha iyidir!" Büyük Don'un kıyılarında pek çok askerin cesedinin yattığı sırada, Rahip Peresvet rüzgâr gibi atını dörtnala koşturup altın zırhını parlattı.

Böyle bir zamanda yaşlı adam gençliğini hatırlayarak, babayiğit insanlarına kendi kahramanlığını ve tecrübelerini aktarmak istedi. Rahip Oslyabya ${ }^{20}$ manevî kardeşi olan Aleksandr Peresveta'ya şöyle dedi: "Kardeşim Peresvet, vücudunda ağır yaraların izlerini görüyorum. Kardeşim artık Büyük Knyaz Dmitriy İvanoviç'in hataları yüzünden Rus toprakları ve Hristiyan inancı için başın otlara düşmesin, yine oğlum Yakov’un başı Kulikov bozkırlarındaki Nepryada Nehrinin yakınlarındaki yeşil otlara düşmesin”.

Bu zamanda Don yakınlarındaki Ryazan topraklarındaki bozkırlar boyunca ne çiftçiler, ne çobanlar bağırmadılar, insanlığın ve erkek cesetlerinin otların altında kaldığında kargaların (kuzgunların) sesleri hiç kesilmedi, çimlerin 
üzeri kanla dolduğunda ve ağaçların dalları üzüntüden yere eğildiğinde bunların çıkarttığı sesleri duymak korkunç ve şiddetli idi.

Kuşlar büyük bir hüzün içerisinde şarkılarını söylerken ölen voyvoda ve boyarların eşleri ile çariçeler de ağladılar. Mikula Vasilyeviç’in hanımı Marya sabah erkenden Moskova surlarına gelerek gözyaşları içerisinde ağıtlar yakarak şöyle dedi: "Ah Don, Don, Taş Dağları'ndan ${ }^{21}$ ve Kuman/Kıpçak topraklarından akan hızlı nehir. Saygıdeğer Mikula Vasilyeviç’i dalgalarınla bana getir!”. Yine Timofey Voluyeviç Fedosiya ağlayarak ağıtlar yakıp şöyle dedi: "Kutsal Moskova şehrinin neşesi yok oldu (cesareti ve ümidi kırıldı), artık knyazımı tekrar canlı göremeyeceğim!” Andrey’in hanımı Mariya ve Mihail'in karısı Aksiniya şafakta feryatlar içerisinde ağlayarak şöyle dediler: "Artık kutsal Moskova şehrinde güneş bizim için parlamıyor. Hızlı akan Don'dan bize büyük keder yaşatan üzücü haberler geldi: Kulikovo bozkırlarındaki Nepryada Nehrinde rüzgâr gibi hızlı dört nala koşan atları ile askerlerimizin öldüğ̈ haberleri geldi!”

Bu sırada Div (Dev) Tatar kılıçlarının altında bağırıp inlerken, Rus kahramanları yaralandılar.

Şurlar ${ }^{22}$ Akim (İoakim) ve Anna $^{23}$ günü olan pazar günü şafak vakti şehrin surlarında Kolomna'da kahırlı şarkılar söylediler. Bu acılı şarkılar Şurların erken söyledikleri şarkılar değildi - Kolomnalı kadınlar ağıtlar yakarak şöyle dediler: "Moskova, Moskova, hızlı akan nehir, niçin Kuman/ Kıpçak topraklarındaki dalgaların bizim eşlerimizi aldı?” Daha sonra şöyle devam ettiler: "Saygıdeğer Büyük Knyaz bu mümkün mü? Don'un etrafını küreklerle çevirmedin mi, Don’u miğferlerle boşaltmadın mı? Meça Nehri'nin çimenlerini Tatar cesetleri ile doldurmadın mı? Büyük Knyaz efendim, Oka Nehri yakınlarındaki geçidi alçak Tatarların daha fazla ilerlemesini engellemek için kapat ki bize doğru gelmesinler. Bizim ordumuz ve eşlerimiz öldüler.

Meryem Ana’nın doğum günü olan cumartesi gününde Kulikovo bozkırlarındaki Nepryada Nehri'nde Hristiyanlar pis alayları yendi.

Knyaz Vladimir Andreeviç ordusu ile alçak Tatar alaylarının üzerine atılarak, altın yaldızlı miğferlerini söndürdü. Bu sırada Kuman/Kıpçak miğferleri ve demir kılıçlar şakırdadılar.

Büyük Knyaz Dmitriy İvanoviç’i kardeşi överek şöyle dedi: "Ağabeyim 
Dmitriy İvanoviç, sen çok kötü bir zamanda bize sağlam bir kalkan oldun. Büyük Knyaz kahraman alaylarınla vazgeçme, asilere göz yumma! Biliyorsun ki alçak Tatarlar bizim topraklarımızı ezdiler ve cesur drujinalarımızın birçoğunu öldürdüler- çimenlerde birçok askerimizin cesedini bıraktılar, dörtnala koşan atlar koşamadılar ve şunları söyleyemediler: (toprak) dirseklerimize kadar kan doldu. Kardeşim bu kadar çok Hristiyanın kanının dökülmesine üzülüyoruz.

Büyük Knyaz kendi boyarlarına ağırdan almayın, acele ediniz dedi.

Ve Büyük Knyaz Dmitriy İvanoviç kendi boyarlarına şöyle dedi: "Kardeşlerim, boyarlarım, voyvodalarım ve boyar çocuklarım, burası sizin için Moskova'nın peteği ve büyük harika bir yeri! İşte burada kendinize ve eşlerinize bir yer edinin. Ama kardeşlerim yine de çok yaşlanmayın zira gençken şerefimiz için (onurlu) ölmek daha iyidir”.

Büyük Knyaz Dmitriy İvanoviç: “Tanrım, sana güveniyorum, bana hiçbir zaman utanç yaşatma ve düşmanlarımı hiçbir zaman güldürme!” Diye bağırarak Tanrı'ya, onun temiz annesine ve bütün azizlere dûa ederek, acı içeresinde ağladı ve gözyaşlarını sildi.

Bundan sonra şahinler Don'a doğru hızlıca uçtular. Bir tane şahin uçmadı ve Büyük Knyaz Dmitriy İvanoviç ona bindi ve alayları Don'un arkasına doğru giderken bütün Rus askerleri de onu tâkip ettiler. $\mathrm{O}$ şöyle dedi: "Kardeşim Knyaz Vladimir Andreeviç, burada kendi alaylarında güçlü alçak Tatar alaylarını yenmeden ballı börekleri yiyerek sarhoş olma. Büyüyelim, kardeşim".

Ve bundan sonra Büyük Knyaz saldırıyı başlattı. Demir kılıçlar ve Kuman/ Kıpçak miğferleri şakırdadı. Kötüler kendi elleri ile canlarını verdiler. Alçaklar tekrar geriye doğru çekildiler. Rüzgâr Büyük Knyaz Dmitriy İvanoviç'in bayrağına doğru kuvvetlice esti, dinsizler geriye doğru kaçarken, Rus yurdunun evlatları geniş bozkırlarda çitle çevrili alanları ve yaldızlı zırhları yaktılar. Savaş henüz bitmedi!"

Büyük Knyaz Dmitriy İvanoviç ve kardeşi Knyaz Vladimir Andreeviç’in alayları alçaklar tekrar geri döndüklerinde onları öldürmeye, amansızca, merhametsizce kılıçtan geçirmeye başladılar ve üzerlerine keder, kasvet çöktü. Beyleri atlarından düştü, toprak Tatar cesetleriyle örtüldü ve kanları nehirde aktı. Alçaklar panik içerisinde etrafa kaçışıllar ve Lukomor $^{24}$ yollarında 
(açılmamış yollardan) kendilerine gelemeden, dişlerini gıcırdatarak ve yüzlerini yırtarak kaçtılar ve şöyle söylemek istediler:

"Artık kardeşlerim bizim için bu topraklarda yaşamak, çocuklarımızı görmek ve hanımlarımızı sevmek mümkün değil, biz sadece bu nemli toprakları okşayabilir, bu yeşil çayırları öpebiliriz, Rus orduları bundan böyle bize yaltaklanmazlar ve Rus knyazlarından vergi isteyemeyiz”. Bu şekilde Tatar topraklarına üzüntü, acı ve keder indi; Hanlar Rus topraklarına gitmek için memnuniyetle mahvolmak istediler. Onlar için eğlence, sevinç bitti.

Şimdi Rus evlatları Tatarların nakışlı zırhlarını, atlarını, öküzlerini, develerini, şaraplarını, şekerlerini ve diğer pahalı mobilyalarını, ince ve ipekli kumaşlarını ele geçirerek eşlerine götürdüler. Rus hanımları Tatar altınları ile zenginleştiler.

Rus topraklarına neşe ve sevinç yayıldı. Rus onuru alçakların yerme, aşağılamalarının üstesinden geldi. Div artık bu topraklarda alaşağı edildi, yıkıldı, Büyük Knyaz Dmitriy İvanoviç ve kardeşi Vladimir Andreeviç’in onuru ve dehşeti bütün topraklara taşındı. Vur Büyük Knyaz, Hristiyan inancı ve Rus toprakları için Büyük Knyaz alçak Kıpçak Mamay’n cesur savaşçlarını bütün Ryazan toprakları boyunca vur. Alçaklar silâhlarını bıraktılar ve Rus kılıçları karşısında başlarını eğdiler. Artık davullar çalmıyor, sesleri kesildi.

Gri kurt olarak bilinen askerleri ile alçak Mamay ne yapacağını bilemez hâlde Kefe Şehrine kaçtı. Fryaglar ${ }^{25}$ O’na şöyle söylediler: “Alçak Mamay neden Rus topraklarına göz diktin? Zaleskiy ordası şimdi seni yendi. Batu Han'dan çok uzaklardasın: Batu Han'ın yanında dörtyüzbin zırhlı var ve o doğudan batıya kadar bütün Rus topraklarına yerleşti? Tanrı Rus topraklarını günâhlarından dolayı cezalandırdı. Ve sen Emir Mamay Rus topraklarına büyük bir güçle, dokuz orda ve yetmiş bey ile geldin. Ama şimdi sen seninle bu topraklara kışlamak için gelen alçaklarla beraber Lokomor’a doğru dokuz orda ile kaçıyorsun. Rus knyazlarının seni sağlam, güçlü bir şekilde mahvettikleri görülüyor:

Artık yanında ne knyazlar ne de voyvodalar var! Kulikovo bozkırlarından hızlı akan Don yakınlarındaki çimlerde ağır bir yenilgiye uğradığın görülüyor, alçak Mamay, bizden karanlık orman boyunca koşarak kaç!"

Nasıl ki bir bebek annesinin şefkatinde mutlu oluyorsa, Rus topraklarının 
evlatları da annelerinin yanında: anneleri onları okşuyor, şımartıyor ve yaptıklarını övüyor. Tanrı, Don ile Dinyeper arasındaki Kulikovo topraklarında bulunan Nepryadva Nehrinde bütün Rus knyazlarına, Büyük Knyaz Dmitriy İvanoviç ve kardeşi Knyaz Vladimir Andreeviç’e merhametini gösterdi.

Büyük Knyaz Dmitriy İvanoviç kardeşi Knyaz Vladimir Andreeviç ve geride kalan voyvodaları ile Kulikovo bozkırlarındaki Nepryadva Nehri'nde cesetler ile kaldılar. Kardeşler dehşetli ve üzücü bu manzaraya bakarak şöyle dediler: Don sahillerindeki kuru otlarda Hristiyanların onuru yatıyor, Don'da üç gün kan aktı. Büyük Knyaz şöyle dedi: "Kardeşlerim bizim ne kadar voyvoda ve genç insanımız kaldı sayınız, yetiyor muyuz?"

Bunun üzerine Moskovalı Boyar Mihail Aleksandroviç, Knyaz Dmitriy İvanoviç’e şöyle cevap verdi:

"Saygıdeğer Büyük Knyaz Dmitriy İvanoviç! Biz Moskovalı kırk boyar, Beloozerolu oniki knez, Novgorodlu otuz atl, Kolomanalı yirmi boyar, Sephonovlu kırk boyar, Litvanyalı otuz toprak sahibi, Pereyeslavlli kırk boyar, Kostromalı yirmibeş boyar, Vlimirli otuzbeş boyar, Suzdallı elli boyar, Muromlu kırk boyar, Ryazanlı yetmiş boyar, Rostovlu otuzdört boyar, Dmitrovlu üç boyar, Mojalı atmış boyar, Zvenigorodlu otuz boyar, Ugliçli onbeş boyarı kaybettik. Ama Tanrısız Mamay ikiyüz elliüçbin askerini kaybetti. Tanrı bu kadar sayısız kalabalık olan Tatar ordusundan Rus topraklarını korudu, merhamet etti”.

Büyük Knyaz Dmitriy İvanoviç şöyle dedi:

Don ve Dinyeper arasındaki Kulikovo bozkırlarında bulunan Nepryada Nehri'ndeki kardeşlerim, boyarlar, knyazlar ve boyar çocukları. Hristiyanlık, Rus toprakları ve kutsal kilise için canlarınızı verdiniz. Beni affediniz kardeşlerim ve gelecekte bu nehirde yaşananları minnetle anınız. Haydi! Kardeşim Knyaz Vladimir Andreeviç, senin Zaleski topraklarına ve şöhretli Moskova şehrine gidelim ve burada kardeşim, çariçenle onurumuzla güzel bir ad alarak oturalım!" Tanrı şanımızı korusun!" (Lihaçev 1981: 184-200).

Destan metninden de anlaşılacağı üzere destan yazarı önce Rusların Nuh'un oğlu Yafes'in soyundan geldiklerini belirtmektedir ki Rus yıllıklarının da ilk cümleleri bu aidiyetin ifade edilmesi ile başlamaktadır. Altın Orda hâkimiyetine karşı aralarında tam bir birliktelik oluşturamadıkları 
için yıllarca onların hâkimiyetinde kalmak zorunda oldukları üzerinde durularak, bu hâkimiyete karşı birlikte hareket etmeleri gerektiği ve bu hususta kendilerine dost olanlardan (Litavlar) yardım istemeleri gerektiği belirtilmektedir. Ancak bazıları bu yardıma itiyatla yaklaşmakta ve bu birlikteliğin kendilerine ne kazandıracağı üzerinde durmaktadır.

Destan yazarı inanmış koyu bir Hristiyan olduğu için Rus milletinin yaşadığı bütün olumlu veya olumsuz hadiseleri Tanrı’ya bağlamakta, yaşanılan yenilgiler Tanrı'nın bir cezası, zaferler ise mükâfatı olarak gösterilmektedir. Hristiyan inancı için can verme ve kan akıtma anlayışı bu yüzden destanda sıkça tekrarlanmaktadır. Ayrıca Tanrı’nın istediği gibi hareket edilmediğinde vereceği cezanın ne kadar büyük olduğu da hatırlatılmaktadır.

Destan savaşın sonunda galibiyeti ve büyük zaferi kazanan Rusların, Altın Orda’ya ve Mamay'a artık o topraklarda yaşama hakkı vermediklerini, Tatar ordusuna ait bütün ağırlıkları ele geçirdiklerini ve Tatarların bundan sonra vergi istemeye yüzlerinin kalmadığını ifade etmektedir.

Bu destanın bir diğer özelliği de yukarıda ifade ettiğimiz gibi 1185 yılında Kuman/Kıpçaklara karşı kazanılan savaşın edebiyattaki yansıması olan İgor Bölüğü Destanı'nın konusuna olan benzerliğidir. Bu destan tarafımızdan çalışılmıştır (Yücel 2006: 523-559). Bu destan ile ortak unsurlar arasında Kâhin Boyan ve Div'in yanı sıra bozkurt, kartal, kuğu, şahin tilki, bülbül, alacakarga, sugur gibi hayvanların manevi yönden ifade ettikleri anlamlar yer almaktadır. Kaz ve kuğu eski Rus folklorunda kötü motiflerdir. Bu yüzden destanda Ruslar şahin, Tatarlar ise kaz veya kuğu olarak gösterilmişlerdir. Ayrıca destanda Türk kültüründe önemli bir motif ve sembol olarak karşımıza çıkan kurt; gri bozkurt motifi ile Mamay'ın askerlerini ifade etmek için kullanılmıştır.

Destanda 43 tane Türkçe kökenli kelime vardır. Efendiyeva bu kelimeleri kendi aralarında şu şekilde gruplandırmıştır: Onomastik Birimler (antroponimler 7: Mamay, Batıy, Boyan, vs; etnonimler 9: Tatar, Polovts1 (Kuman/Kıpçak), Olberı, Hinovya vs; toponimler 3: Kiyev, Kayala, Kafa/ Kefe); İnsanla ilgili kelimer 3: bogatır, katun, busormanovya: Müslüman); Bina ve ev ile ilgili kelimeler 1: Telega; Bitki ve hayvan dünyası ile ilgili kelimeler 8: Turı (yabansığırı), vol (öküz) vs; sosyal teminolojiye (töre, örf, adet ile ilgili kelimeler 2: Çara: Kadeh, büyük bardak vs; askeri kelimeler 9: 
Meç. Kılıç, sulitsa askerî silah vs, sosyal kelimeler 1: Boyarin (boyar). (2001: 582-585)

Kısacası destan, Rus maneviyatını Altın Orda karşısında yüceltmek için yazılmıştır. Nitekim Tatarlar ve Mamay hep pis, alçak, Tanrısız, iğrenç sıfatı ile anılırlarken Ruslar, Tanrı'nın merhametine mazhar olmuş güçlü Hristiyanlar olarak verilmişlerdir.

\section{Sonuç}

Moskova Knyazı Dmitriy’in Altın Orda Emiri Mamay’a karşı Don Nehri yakınlarında gerçekleştirdiği bu savaş, Rus milletinin milletleşme sürecine en büyük katkıyı sunan bir zafer olarak tarihte yerini almıştır. Zira bu zafer onlara uzun yıllar hâkimiyetleri altında yaşamak zorunda kaldıkları Türkleri bir araya geldiklerinde yenebilecekleri duygu ve düşüncesini vermiştir. $\mathrm{Bu}$ zaferden sonra toparlanan knyazlıklar mücadelelerine büyük bir manevi güç ile devam ederlerken; bu yenilgi ile büyük bir güç kaybeden Altın Orda devleti ise hızlı bir çöküş sürecine girmiştir. Bu zafer maalesef Altın Orda’nın "Büyük Duraklama veya Fetret Dönemi" denilen döneminde yaşanmıştır.

Zaferin yaşattığı haz ve hissettirdiği güç halk arasında çeşitli destanların ortaya çıkmasına ve bunlar vasıtası ile bu duyguların gelecek nesillere aktarılmasına sebep olmuştur ki bu destanlar arasında Zadonşina da en önde gelenler arasında yerini almıştır. Bu destan her iki tarafı kıyaslamaya tabi tuturak, Hristiyan Rus gücünün birleştiğinde neler yapabileceğini gösterirken, yüzyıllardır süren Tatar tahakkümünü nasıl yenebileceklerini de ortaya koyma gayreti içerisinde olmuştur. Destan Ruslarda millet olma şuuru içerisinde hareket etme duygusunun yaygınlaşmasını sağlarken, aslında kültürel olarak da Türklerin ne kadar çok etkileri altında kaldıklarını özellikle kullanılan kelimeler ve motiflerde gözler önüne sermiştir.

\section{Açıklamalar}

1 Kafalı, Abdulgaffar Kırımî̀den naklen Mamay'ın Canı-Bek Han'ın kızı ile evlendiğini söylerken (40); Yakubovskiy, İbn Haldun'dan naklen Bedri-Bek Han'ın kızı ile evlendiğini söylemektedir (118).

2 1382-1386 yılları arasında Litvanya tahtında oturmuştur.

3 Kulikovo zaferinin yaşandığı yerin tam neresi olduğu konusunda da çeşitli görüşler ileri sürülmüş. Son yıllarda yapılan çalışmalardan biri de $S$. A. Azbelev'e aittir ve o, Kulikovo düzlüklerinin ve Nepryadva Nehri'nin 
günümüzde Tulkoy bölgesinde, Don Nehri’nin sağ kıyısında yer aldığını ispatlamıstır (Azbelev 2012: 43-52).

4 Savaşın bütün detayları Nikonov yıllığında anlatılmaktadır. (Nikonovskaya Letopis XI: 45-70).

5 Anıtın altında "Tatar Kahramanı Büyük Knyaz Dmitriy İvanoviç’e Soyu Münnettardır” yazılmaktadır.

6 Eski Rusçåda Oka ile İtil nehirleri arasındaki topraklara verilen isimdir ve o dönemde Suzdal-Vladimir (Rostov-Suzdal) Knyazlığı topraklarıdır.

7 Hinova kelimesi hem İgor Bölüğü Destanı'nda hem de Zadonşina da geçmektedir. Bu kelime ile ne ifade edilmek istendiği hakkında çeşitli görüşler öne sürülmüştü. Mesela: Miller'e göre bu Fin kelimesinin eski Rusça söylenişidir (Hinova (1914). "Slovo o polku Иgorevo". ИОРЯ: Известия Отделения русского языка и словесности Академии наук. т (c). XIX. 110-118), Potebniya’ya göre Kuman/Kıpçakları veya Hunlar gibi diğer bozkır milletlerini ifade etmektedir (A. A.Potebniya (1914). "Slovo o polku Kgorevo". Tekst i Primę̧. İzd. 2-e. Harkov. 113-114): Rasovskiy, İdrisi'nin Azak Denizi'nin kuzeyinde nerede olduğu tam olarak tespit edilemeyen ve Kuman/Kıpçakların oturduğu yerin adı olarak verdiği Kinov şehri olmadığını (bu şehirde oturan halkın bu adla anılmadığını) ifade ederek bu kelimenin Kuman/Kıpçakların arasında yaşayan çeşitli halkları ifade ettiğini belirtmektedir. (D.A. Rasovkiy (1936). "Hinova". Seminarium Kondakovianum. t. VIII. Praha. 305-6) M. Şeftel, Macarları kastettiğini söylemektedir (M. Şeftel (1948). La Geste du Prince Igor'. New York. 123, 131); Gy. Moravcisk, XI-XII. yüzyıllar arasında Macarların Hun adı ile anıldıklarını söylemektedir. (Gyula Moravcsik (1960). "Zur Frage der Хинове im Igor-Lied”. International Journal of Linguistics and Poetcs. t. III. 69-72).

8 Burada басурманы: Basurmanı kelimesi ile kastedilen Müslümanlardır.

9 Guslyar telli bir eski Rus sazıdır.

10 "İgor Bölüğü Destanı"nda ve "Zadonşina"da geçen Boyan, ilerisini gören ozan, âşık ve şarkıcıdır.

11 Moskova yakınlarında Oka Nehri üzerinde kurulan şehir.

12 Moskova’nın güney bölgesinde Nar Nehri üzerinde kurulan şehir.

13 Günümüzde Krasivaya Meça olarak adlandırılmaktadır. Rusya'da Tulkoy ve Lipets bölgesinde akan Don'un kollarından biri.

14 Bu kelime ile 1316-1341 yılları arasında hüküm süren Büyük Litvanya Knyazı Gedimin kastedilmektedir.

15 Beloozero, Sankt-Peterburg şehrinden geçen, Büyük Neva Gölünde bulunan Krestov Adası'nda yaşayan eski Doğu Slav kabilelerinden Dvoryanların 
kurduğu şehir. Bu şehir ismini Knyaz Belozerski’den almıştır.

16 Büyük Kiev Knyazı Vladimir Svyatoslaviç’in Bizans prensesi Anna’dan doğan çocukları. Babalarının ölümünden sonra çıkan taht kavgası sırasında her ikisi de 1015 yılında öldürülmüş ve kendileri Rus kilisesinin ilk azizleri olarak kabul edilmişlerdir.

17 Tuna Nehri boyunca Karpat Dağlarına kadar olan yakın bölge kastedilmektedir.

18 Troits-Sergiyev Manastırının rahibi Aleksandır Peresvet, Kulikovo Savaşının kahramanları arasındadır. Savaş sırasında Tatar savaşçı Çelibe (başka bir görüşe göre de Temir-Mirza) ile güreşerek ölmüştür

19 Desna Nehri yakınları ile Çernigov ve çevresinde Çernigovlu Mihail Vsevolodoviç tarafından kurulan Buryat Knyazlığına (1246-1401) ait askerler.

20 Troitsko-Sergieevo Manastırının rahibi. Asıl adı Rodion (Roman) Osliyabiya. Kulikovo savaşı sırasında ölmüştür.

21 Metinde каменные горы: Taş Dağları ve Taş Kayalar olarak verilen bu bölge günümüzde Rusya Federasyonu içerisinde Yayık Nehri'nin ortasında bulunan Revda bölgesinde bulunmaktadır.

22 Bir kuş cinsi. Latince adı Pinicola olan Şur kuşunun gagası biraz uzundur.

23 Kutsal İoakim ve Anna Anglikan, Katolik ve Ortodoks Mezhebine göre Meryam Ana'nın anne ve babasıdır.

24 Лукоморье (Lukomor): Rus Yıllıklarında ve Zadonşina Destanında Kuman/ Kıpçakların yaşadığı bölgelerden biri olarak geçmektedir. Bulunduğu yer Don'un aşağısı, Azak Denizi ile Karadeniz'nin kıvrımları ile Özi Nehrine yakın bir yerde idi.

25 Фряги: Fryagi veya Fryazi, Eski Rusça’da Kırım ve Ten'de ticaretle uğraşan İtalyan tüccarlara özellikle de Venedikli ve Cenovalı tüccarlara verilen isimdir.

\section{Kaynaklar}

Azbelev, Sergey Nikolayeviç (2011). Kulikovskaya Pobeda v Harodnoy Pamyati: Literaturnuye Pamyatniki Kulikovskogo Tsikla i Folklornaya Traditsiya. Moskva. (Erişim Tarihi 02.02.2017).

Azbelev, Sergey Nikolayeviç (2012). "O Geografii Kulikovskoy Bitvı”. Ruskoye Pole 2: 43-52.

Efendiyeva, Çiçek (2001). "Zadonşina Adlı Eski Rus Eserindeki Eski Türk Kökenli Kelimeler Üzerine Bir İnceleme”. Türk Dili 593: 580-588.

Kafalı, Mustafa (1976). Altın Orda Hanlığının Kuruluş ve Yükseliş Devirleri. İstanbul. 
Kamalov, İlyas (2009). Altın Orda ve Rusya. İstanbul: Ötüken Neşriyat.

Kurat, Akdes Nimet (1987). Başlangıçtan 1917’ye Kadar Rusya Tarihi. Ankara: TTK Yay.

Lavrentev, Aleksandr Viladimiroviç (2015). “'Zadonşina' Ryazan i Moskovskaya Velikoknyajeskaya Semya”. Slověne 2: 320-251.

Letopisnıy Sbornik Patriarş ili Nikonovskoyu Letopisyu, Polnoye Sobranie Russkih Letopiseh. IX-XI (1897). Sankt-Peterburg.

Lihaçev, Dimitriy Sergeyeviç (1966). "O Nazvaniya 'Zadonşina'". İssledovaniya Po Oteçestvennomu İstoçnikovedeniyu. Moskova-Leningrad. 474-475.

Lihaçev, Dimitriy Sergeyeviç (1981). Zadonşina. Pamyatniki Literaturı Drevney Rusi XIV-Seredina XV Veka. Moskva.

Nasonov, Arseni Nikolayeviç (1940). Mongoli i Rus. Moskva-Leningrad.

Pamyatniki (1998). Pamyatniki Kulikovskaya Tsikla. Red: Boris Aleksandroviç Ribakov. Sankt-Peterburg.

Polnoye Sobraniye Russkih Letopisey (2000). Tverskaya Letopis. Haz. Aleksandr İivanoviç Çepkov. T. VI. Ryazan.

Solovyev, Aleksandr Vasilyeviç (1958). "Avtor 'Zadonşını' i ego Politiçeskiye İdei”. Trud Otdela Drevnerusskoy Literaturn 14: 183-197.

Şirokorad, Aleksandr Borisoviç (2005). Kulikovskaya Bitva i Rojdeniye Moskovskoy Rusi. Moskva: Veçe Yay.

Troitskaya Letopis (1950). Haz. Mihail Dimitriyeviç Priselkov. Moskva-Leningrad. Uydu Yücel, Mualla (2006). "Kuman/Kıpçaklar'ın Tarihinde İgor Destanının Yeri ve Önemi”. Belleten 258: 523-559.

Uydu Yücel, Mualla (2008). “1224 Kalka Meydan Muharebesinin Rövanşı: 1380 Kulikovo Meydan Muharebesi ve Bu Muharebenin Rus Tarihi Açısından Önemi”. Prof. Dr. Gülçin Çandarlıoğlu Armăganı. İstanbul.

Yakubovskiy, Aleksandr Yureviç (1992). Altın Orda ve Çöküşü. Çev. Hasan Eren. Ankara: TTK Yay.

\section{İnternet Kaynakları}

Dmitriyeva, R. P. Bıl li Sofoniy Ryazanets Avtorom Zadonşini? odrl.pushkinskijdom. ru/ (Erişim Tarihi: 22.01.2017).

http://www.vokrugsveta.ru/telegraph/history/427/ (Erişim Tarihi: 22.01.2017).

http://hrono.ru/biograf/bio_m/mamai.php (Erişim Tarihi: 22.10.2016).

http://konevodstvo.su/books (Erişim Tarihi: 30.01.2017).

http://photo-drive.ru/wordpress/kulikovskaya-bitva (Erişim Tarihi: 04.02.2017). 


\title{
The Reflection of the Golden Horde-Russian Struggle to Literature: The Epic of Zadonşina*
}

\author{
Mualla Uydu Yücel $^{* *}$ \\ Ainagul Saginayeva**
}

\begin{abstract}
The Mongols that began to dominate the Russian lands from the first quarter of the 13th century, were increasingly stronger from the second half of that century and thus leading the establishment of the Golden Horde state, including various Turkic tribes. Following the 13th century's first quarter, the growth of Golden Horde (Altin Orda) Khaganate quickly completed in a way to rule the Russians lands and Russian Knezs could stand neither politically nor militarily against this power. However, after the 14th century's second half, the power erosion in Golden Horde (Altin Ordu) reflected clearly in 1380 with Kullikova Battle between Golden Horde (Altin Orda) Amir Mimay Mirza and Moscow Knez Ivan from the Moscow. In this battle Golden Horde was enfeebled. Considering the historical process, while Kulikova meant an inevitable end as a beginning of a disintegration and a fall for Golden Horde, for Russians it meant to over the period of stagnation with unity and great victory to take the revenge of Kalka. Another important feature of this victory is that the Russians have taken their place in the history stage with the awareness of "Russian nation" after this war. One of the epics that is thought to have been written right after this war is the Zadonşina epic. In our study, the text of the epic was translated into Turkish and it was tried to be interpreted.
\end{abstract}

Keywords

Russian Knezes, Golden Horde, Moscow, Mamay, epic, Dmitry.

Date of Arrival: 1 March 2017 - Date of Acceptance: 22 February 2018

You can refer to this article as follows:

Uydu Yücel, Mualla and Ainagul Saginayeva (2020). "Altın Orda-Rus Mücadelesinin Edebiyata Yansıması:

Zadonşina Destanı”. bilig - Journal of Social Sciences of the Turkic World 93: 149-179.

"* Prof. Dr., İstanbul University, Faculty of Letters, Department of History - İstanbul/Turkey

ORCID ID: 0000-0002-1595-2106

mualla.yucel@istanbul.edu.tr

${ }^{* * *}$ Dr., Al-Farabi Kazakh National University, Department of History - Almaty/Kazakhstan

ORCID ID: 0000-0003-4871-972X

aikos-1978@mail.ru 


\title{
Отражение в литературе противостояния Руси и Золотой Орды: «Задонщина»
}

\author{
Муалла Уйду Юджель ** \\ Айнагуль Сагинаева ${ }^{* * *}$
}

\begin{abstract}
Аннотация
С первой четверти XIII века русские земли оказались под властью монголов, которые, став еще сильнее со второй половины столетия, приступили к созданию государства Золотая Орда, включая в него различные тюркские племена. Укрепление Золотой Орды было завершено за очень короткое время, и русские князья не могли показать никакого сопротивления перед лицом этой власти как в политической, так и в военной сферах. Однако нараставшая в Золотой Орде со второй половины XIV века эрозия власти отчетливо проявилась в 1380 году в Куликовской битве между ордынским военачальником Мамаем и московским князем Дмитрием Донским. В этой битве Золотая Орда была ослаблена.

Анализируя этот исторический процесс, можно сказать, что Куликовская битва подготовила неизбежный конец Золотой Орды, то есть начало распада и вымирания, в то время как для русских битва была большой победой, означала выход из периода застоя и возможность отомстить после Калки. Другим важным моментом этой победы было осознание русскими себя как русского народа, его появление впоследствии на исторической арене как такового. Одним из сказаний, написанных, как считается, сразу после битвы, является «Задонщина». В этом исследовании сказание будет переведено на турецкий язык с целью интерпретации.
\end{abstract}

\section{Ключевые слова}

русские князья, Золотая Орда, Москва, Мамай, сказание, Дмитрий.

\footnotetext{
* Данное исследование было подготовлено на основе доклада, который предполагалось представить на 1-м Национальном конгрессе тюркологов, состоявшемся в 2014 году. Поступило в редакцию: 01 марта 2017 г. - Принято в номер: 22 февраля 2018 г.

Ссылка на статью:

Uydu Yücel, Mualla ve Ainagul Saginayeva (2020). “Altın Orda-Rus Mücadelesinin Edebiyata Yansıması: Zadonşina Destanı”. bilig - Журнал Гуманитарных Наук Тюркского Мира 93: 149-179.

*** Проф., д-р, Стамбульский университет, Филологический факультет, кафедра истории Стамбул / Турция ORCID ID: 0000-0002-1595-2106 mualla.yucel@istanbul.edu.tr

*** Д-р, Казахский Национальный университет им. Аль-Фараби, исторический факультет Алматы / Казахстан ORCID ID: 0000-0003-4871-972X aikos-1978@mail.ru
} 